\title{
Arabic Language Teachers Teach and Collaborate through Mobile Instant Messaging: Analysis of Use, Benefits, and Challenges in Jordan
}

\author{
Suad A. Alwaely \\ Department of Curriculum and Instruction (C\&I), The Hashemite University, Zarqa, Jordan
}

\begin{abstract}
The current study aimed to examine Arabic language teachers' perceived competence, use, benefits, and challenges of WhatsApp use as an educational tool. A questionnaire as a quantitative data collection method was used. The findings revealed that participants had different levels of WhatsApp integration skills, with $44 \%$ of them being advanced or expert and $56 \%$ being intermediate or beginner users. The study also found that participants used WhatsApp primarily for sharing and accessing language materials and for chatting purposes. It was also revealed that participants perceived WhatsApp as a beneficial collaborative language educational tool. Yet, participants identified a number of challenges, such as requiring extra effort and time to use, digital divide, students' improper use, smartphones' screen size, and failure to deliver effective instruction.
\end{abstract}

Index Terms - Arabic, instant messaging, mobile technology, use, teachers, WhatsApp

\section{INTRODUCTION}

The use of such mobile technologies as smartphones and their apps, which is revealed by the high rate of ownership of those devices among teachers and students, has been rising speedily (So, 2016). This technology that allows teachers and students access to a variety of resources via Wi-Fi, cellular data plans, or Internet connections has the power to change teaching and learning, with excessive potential both inside and outside the classroom (Sung, Chang, \& Liu, 2016). It is used in a variety of teaching and learning settings, with numerous positive impacts, including increasing autonomous and self-paced individual learning (Domingo \& Garganté, 2016; Lu, Meng, \& Tam, 2014), providing a variety of authentic learning settings (Boticki, Baksa, Seow, \& Looi, 2015), enhancing enjoyment and promoting motivation to learn (Furió, Juan, Seguí, \& Vivó, 2015), facilitating immediate access to digital content (Domingo \& Garganté, 2016; Murphy, 2011) and fostering interaction and communication (Churchill \& Wang, 2014).

A very popular example of smartphone apps is WhatsApp instant messaging. It is an app that can be categorized as quasi-synchronous communication (So, 2016). WhatsApp is the number-one mobile messaging app, which enables users to exchange messages across the world at no cost (Mwakapina, 2016). In addition to exchanging short, typed texts, WhatsApp supports sharing hyperlinks, multimedia content, support group communication, and social interaction (So, 2016; Vrocharidou \& Efthymiou, 2012). Research literature revealed that language education can be improved by creating a wide range of valuable and effective learning activities facilitated by the use of WhatsApp (Aburezeq \& Ishtaiwa, 2013; Hamad, 2017; Maria, 2016; Plana et al., 2013).

Just like with any other technological application, teachers have a fundamental role to play to ensure the success of integrating that application as a fundamental part of their teaching. With their attempts to adopt WhatsApp as an example of mobile instant messaging apps for educational purposes, identifying teachers' perceptions towards the benefits and challenges of WhatsApp might be a driving factor to support their use (Baek, Zhang, \& Yun, 2017). Even with wide popularity of WhatsApp among teachers and students, there is very limited research on the use of the app for educational purposes, especially related to Arabic language education. As a consequence, this study aims to explore the Arabic language teachers' perceptions and use of WhatsApp as a tool to support their teaching practice in Jordan.

\section{LITERATURE REVIEW}

\section{WhatsApp Instant Messaging as a Teaching Tool}

The widespread use of mobile devices among educators and students from all levels of education has attracted educators to the use of those devices to support the teaching-learning process (Dhir, Gahwaji, \& Nyman, 2013; Ishtaiwa, 2014; Kinash, Brand, \& Mathew, 2012). This attractiveness could be justified by the valuable features of smartphone apps that provide distinctive educational benefits. Such features include affordability, functionality (Kinash et al., 2012), movability, context sensitivity, social interactivity, connectivity, and independence (Klopfer, Squire, \& Jenkins, 2002). With those features, the teaching-learning process has become more enjoyable, interesting, convenient, flexible, and 
effective (Ishtaiwa, 2014; Peng, Su, Chou, \& Tsai, 2009).

WhatsApp is a smartphone app that has been persuasive among teachers and students. It is a free instant messaging platform operated on smartphones devices. Users can send text messages, images, audio, or video clips. In addition, it can be used for voice calling as well as for voice recording to send audio messages instead of written ones. The comparison of WhatsApp to communal messaging and social media apps used in education, such as email, SMS, Facebook, and Twitter, reveals that WhatsApp has the following distinctive characteristic. It includes the ability to change the text format, provides information about user availability, eases creating and facilitating learning groups, enables collaborative learning, eases sharing content, and has a high level of privacy and security (Bouhnik \& Deshen, 2014).

It is an appropriate tool to facilitate the "bite-sized approach", which allows teachers to convey learning materials in small pieces. This approach has many advantages, such as easing the learning process and making it less overwhelming. WhatsApp also chronologically stores those small pieces of learning materials, where students can easily and conveniently access and revisit them. This easy, convenient, and on-demand access is also useful for students with special needs, which enables meeting their individual differences (So, 2016). Through formal and informal communication supported by WhatsApp, students are able to break down traditional boundaries, reach their teachers with confidence, and promote their interest and success in their learning journey (Cifuentes \& Lents, 2010). The WhatsApp platform can also be used to provide students with meaningful means for co-creation of educational materials and constructing meaning and understanding (So, 2016).

\section{WhatsApp and Language Education}

Although substantial work has been conducted on the use of mobile apps for language teaching and learning (Cavus \& Ibrahim, 2009; Lu, 2008; Zhang, Song, \& Burston, 2011), most of those research studies concentrated on textmessaging apps, such as SMS, or on PC instant messaging applications (So, 2016). The limited research studies discussed the use of WhatsApp as a mobile instant messaging app for language education and revealed that WhatsApp has the power to improve language education and to advance students' language proficiency (Abdul Fattah, 2015; Andújar-Vaca \& Cruz-Martínez, 2017; Hamad, 2017; Maria; 2016; Plana et al., 2013).

The strengths of WhatsApp lie in its ability to provide opportunities for collaborative learning, which is necessary for language learning (Aburezeq \& Ishtaiwa, 2013; Hou \& Wu, 2011). Mwakapina (2016) asserted that language is best learned when there is adequate space for communication and dialogue. Aburezeq and Ishtaiwa (2013) asserted that WhatsApp is a successful tool to enhance student collaboration with peers, instructors, and content by offering a userfriendly platform for communicating and sharing ideas and information beyond the class time. WhatsApp allows teachers and students to send and receive an indefinite number of messages through creating and facilitating learning groups. Another strength of WhatsApp, as Hamad (2017) and Plana et al. (2013) reported, is rising enthusiasm and increasing engagement in learning activities. WhatsApp offers an authentic environment where students can discuss ideas, construct meaning, evaluate, and reflect on their performance "on the go", regardless of constraints of time and place (Andújar-Vaca, \& Cruz-Martínez, 2017). Cheung, Hew, and Ng (2008) reported that students were fully engaged and actively participating in employing online collaboration tools. Using WhatsApp for educational purposes is reinforced by the social constructivist theory of learning, where students are encouraged to socially interact with each other to create and share their own knowledge (Vygotsky, 1978). Despite that students may extensively use WhatsApp for chatting purposes, which possibly entail using improper language, WhatsApp could help students develop and enhance their language productivity in a new and pleasant way, especially with teachers' constant support for using correct language (Al Shekaili, 2016). Consistently, Army (2014) argued that students' access to a variety of digital learning resources whenever and wherever enhances their deep learning competencies and allows them to create their own knowledge in an interesting environment.

In spite of WhatsApp's valuable benefits to language education, some studies unveiled that mobile short messaging and instant messaging apps have a negative impact on developing students' language proficiency, especially related to vocabulary, spelling, and grammar skills (Rankin, 2010; Salem, 2013). The adverse impact is due to the overuse of clippings and abbreviations that are grammatically incorrect and inaccurate (Salem, 2013). Further discussion of the negative aspects or challenges of WhatsApp is provided in the following section.

\section{Challenges of Using WhatsApp in Language Education}

While WhatsApp provides several benefits to language education highlighted above, the literature also reported some challenges to WhatsApp use. For example, Aburezeq and Ishtaiwa (2013) reported that pre-service language teachers that participated in their study indicated that the use of WhatsApp was hindered by a number of factors related to technology cost, time-consuming and increasing workload, increasing distraction, deficiency of students' commitment to effective contribution, lack of integration skills, and architectural features of smartphones (screen size). Yeboah and Ewur (2014) indicated that the use of WhatsApp leads to procrastination-related problems, damages students' spellings and grammatical language skills, and leads to losing concentration during study time or for an assignment.

Bouhnik and Deshen (2014) categorized the challenges of WhatsApp into three main areas: technical, educational, and academic. The main technical challenges reported were the unavailability of smartphones owned by students and message swamping. However, the expectations of teachers' high level of availability, teachers' exposure to their students' personal lives, and students' use of unsuitable language were the major educational dilemmas. In terms of 
academic challenges, students' use of informal language and lack of some students' enthusiasm to give effort were identified. Similarly, in a later study conducted by Gon and Rawekar (2017), eye strain (technical), confusion due to the massive amount of learning materials (educational), and some students' sharing of material only to impress the teachers (academically) were also recognized as additional challenges. Other challenges documented by Mwakapina, Mhandeni, and Nyinondi (2016) included students' posts of improper materials, difficulty of evaluating students' contributions, losing focus due to unrelated questions, impossibility of blocking posting after the assignment due date, and absence of a mechanism for sorting each student's posts.

\section{Purpose of the Study}

The associated benefits and challenges of WhatsApp create confusion and discrepancy regarding its use as an educational tool. In addition, the literature critically lacks exploration of Arabic language teachers' perceptions of this issue. Given the fact that teachers are an important agent in terms of acceptance and use of such mobile app, this study was carried out to examine Arabic language teachers' perceptions of WhatsApp as a tool to enhance Arabic language education. Mainly, the study examined teachers' competence of using WhatsApp for educational purposes, their actual use of WhatsApp, and their perceptions of the benefits and challenges of WhatsApp. Furthermore, the study examined the impact of teachers' age, gender, and teaching experience on their use of WhatsApp. The study also examined the relationship between teachers' use and their perceptions of competence, benefits, and challenges of WhatsApp.

\section{METHODOLOGY}

\section{Participants}

The study sample consists of 114 Arabic language teachers teaching in 31 public and private schools in Amman, the capital of Jordan, during the first semester of 2017-2018. The convenience sample method was employed to facilitate participation. One of the research assistants $(n=4)$ visited each school multiple times to contact as many Arabic teachers as possible. Those available teachers were asked to fill in the study questionnaire if they had not done so in the previous visit. A summary of participants by gender, age, teaching experience, and highest degree is presented in Table 1 .

TABLE 1

Number of PARTICIPANTS By AGE, GENDER, TEACHING EXPERIENCE, AND Highest DEgREE

\begin{tabular}{|l|l|l|l|}
\hline Category & Sub-Category & Number & Percentage \\
\hline Gender & Male & 44 & $38.6 \%$ \\
\cline { 2 - 4 } & Female & 70 & $61.4 \%$ \\
\cline { 2 - 4 } & Total & 114 & $100 \%$ \\
\hline Age & Under 25 & 21 & $18.4 \%$ \\
\cline { 2 - 4 } & $26-35$ & 58 & $50.9 \%$ \\
\cline { 2 - 4 } & $36-45$ & 22 & $19.3 \%$ \\
\cline { 2 - 4 } & $46-55$ & 11 & $9.6 \%$ \\
\cline { 2 - 4 } & Older than 55 & 2 & $1.8 \%$ \\
\cline { 2 - 4 } Teaching & Total & 114 & $100 \%$ \\
\hline \multirow{5}{*}{ Higherience } & $1-5$ & 50 & $43.9 \%$ \\
\cline { 2 - 4 } & $6-10$ & 32 & $28.1 \%$ \\
\cline { 2 - 4 } & $11-15$ & 15 & $13.1 \%$ \\
\cline { 2 - 4 } & More than 15 & 17 & $14.9 \%$ \\
\cline { 2 - 4 } & Total & 114 & $100 \%$ \\
\hline & MA. & 2 & $1.8 \%$ \\
\cline { 2 - 4 } & Higher Diploma & 8 & $7 \%$ \\
\cline { 2 - 4 } & BA. & 104 & $100 \%$ \\
\cline { 2 - 4 } & Total & 114 & \\
\hline
\end{tabular}

\section{Instrument}

A questionnaire developed by the researchers was used to collect data needed to achieve the purpose of the study. The questionnaire comprised 47 items divided into four categories: demographics (4 items), WhatsApp competence and use (11 items), benefits (15 items), and challenges (17 items) of WhatsApp. Eight educational experts participated in the questionnaire validation process. Several items were added, modified, or deleted, based on comments and feedback from the expert panel. Afterword, the reliability of the questionnaire was assessed by calculating the Cronbach's alpha coefficient for the data collected from 42 teachers that participated in the pilot study. The alpha coefficient was calculated for the whole questionnaire $(\alpha=.85)$ and for each section individually, as follows: WhatsApp use $(\alpha=.77)$, benefits $(\alpha=.90)$, and challenges $(\alpha=.86)$. This indicates that the questionnaire was suitable and valid to achieve the purpose of the study.

\section{Data Collection}

Four research assistants visited each participating school a minimum of three times during the first semester of 20172018 to request participation. All available Arabic language teachers during each visit were invited to take part in the study by completing a hard copy of the study questionnaire. A written consent form, including all necessary information about the study and the data collection process, was given to each Arabic language teacher. The purpose of the consent form was to help teachers choose whether to participate or not.

\section{Data Analysis}


To analyze the collected data, different descriptive and inferential statistical analysis means were used. Particularly, the descriptive analysis involving frequencies, percentages, means, and standard deviations was employed to examine teachers' competence, use, and perceptions of the benefits and challenges of WhatsApp. In addition, teachers' WhatsApp competence and use were characterized into three levels - low (1-2.339), moderate (2.34-3.66), and high (3.67-5) - for interpretation purposes. Furthermore, the inferential analysis involving t-test and one-way analysis of variance (ANOVA) were used to examine the impact of teachers' gender, age, and teaching experience on their WhatsApp use. Lastly, the Pearson correlation was used to examine the relationships between teachers' use and their perceptions of competency, benefits, and challenges of WhatsApp as a language education tool.

\section{RESULTS}

\section{WhatsApp Competence}

To assess Arabic language teachers' competence of using WhatsApp, they were requested to respond to the question: "Which of the following best describes your level of competence of using WhatsApp as an educational tool?" The rating scale was: Novice (1), Advanced Beginner (2), Intermediate (3), Advanced (4), and Expert (5). As shown in Table 2, respondents had various levels of WhatsApp competence $(M=3.42, S D=0.90)$. For example, while $46 \%$ rated themselves at the intermediate level, $44 \%$ of them considered themselves advanced or expert users.

TABLE 2

TEACHERS'SELF-ASSESSMENT OF WHATSAPP COMPETENCE
\begin{tabular}{|l|l|l|}
\hline $\begin{array}{l}\text { Level of WhatsApp } \\
\text { Competence }\end{array}$ & Number & Percentage \\
\hline Novice & 3 & $2.6 \%$ \\
\hline Advanced Beginner & 9 & $7.9 \%$ \\
\hline Intermediate & 52 & $45.6 \%$ \\
\hline Advanced & 36 & $31.6 \%$ \\
\hline Expert & 14 & $12.3 \%$ \\
\hline Total & 114 & $100 \%$ \\
\hline
\end{tabular}

\section{WhatsApp Use}

Arabic language teachers' use of WhatsApp as an educational tool was assessed by asking participants to respond to ten items using a 5-point Likert scale: Never (1), Rarely (2), Occasionally (3), Frequently (4), and Always (5). Table 3 reveals that participants highly used WhatsApp for sharing and accessing language materials $(M=4.01$ and 3.94 , respectively) and moderately for chatting purposes $(M=3.55)$, creating online learning groups $(\mathrm{M}=3.39)$, and providing written or audio feedback (M=3.04 and 2.79, respectively). However', the data analysis indicated that other features of WhatsApp are minimally used to support Arabic education. They include making voice calls $(M=2.14)$, chatting with parents $(M=2.05)$, conducting synchronous online activities $(M=1.83)$, and conducting online assessments $(M=1.65)$.

TABLE 3

TEACHERS' USE OF WHATSAPP

\begin{tabular}{|c|c|c|c|c|c|c|c|}
\hline Activity & 1 & 2 & 3 & 4 & 5 & $\mathbf{M}$ & SD \\
\hline 1) Sharing language-learning materials & 0 & $7 \%$ & $13.2 \%$ & $50.9 \%$ & $28.9 \%$ & 4.01 & 0.84 \\
\hline 2) Accessing language-learning materials & 0 & $11.4 \%$ & $9.6 \%$ & $51.8 \%$ & $27.2 \%$ & 3.94 & 0.91 \\
\hline 3) Chatting with colleagues and students & $5.3 \%$ & $10.5 \%$ & $28.1 \%$ & $36 \%$ & $20.2 \%$ & 3.55 & 1.08 \\
\hline 4) Creating and facilitating study groups & $9.6 \%$ & $5.3 \%$ & $31.6 \%$ & $43 \%$ & $10.5 \%$ & 3.39 & 1.06 \\
\hline 5) Providing written feedback and guidance & $9.6 \%$ & $23.7 \%$ & $28.1 \%$ & $29.8 \%$ & $8.8 \%$ & 3.04 & 1.13 \\
\hline 6) Providing audio messages/lessons & $13.2 \%$ & $24.6 \%$ & $35.1 \%$ & $23.7 \%$ & $3.5 \%$ & 2.79 & 1.05 \\
\hline 7) Making voice calls & $25.4 \%$ & $42.1 \%$ & $25.4 \%$ & $7 \%$ & 0 & 2.14 & 0.88 \\
\hline 8) Chatting with parents & $31.6 \%$ & $38.6 \%$ & $22.8 \%$ & $7 \%$ & 0 & 2.05 & $\mathbf{0 . 9 1}$ \\
\hline $\begin{array}{l}\text { 9) Conducting synchronous online } \\
\text { collaborative-learning activities }\end{array}$ & $41.2 \%$ & $39.5 \%$ & $14 \%$ & $5.3 \%$ & 0 & 1.83 & 0.86 \\
\hline 10) Conducting online assessments & $46.5 \%$ & $43 \%$ & $8.8 \%$ & $1.8 \%$ & 0 & 1.65 & 0.70 \\
\hline
\end{tabular}

\section{Benefits of WhatsApp}

Using a 5-point Likert scale ranging from strongly disagree (1) to strongly agree (5), participants were asked to assess 15 educational benefit statements. Table 4 displays the overall mean of the listed items, ranging from 4.14 to 3.12. This indicates that participants received all the listed statements as benefits of WhatsApp with a different level of influence. For analysis purposes, those benefits were categorized into five groups. As shown in Table 4, Arabic language teachers have perceived using WhatsApp mostly as a tool for sharing and accessing material $(M=3.91)$, creating a motivating learning environment $(M=3.86)$, and supporting collaborative learning $(M=3.74)$. Conversely, providing new educational methods $(M=3.50)$ and improving language education $(M=3.28)$ were the least valued benefits. More specifically, items that received the highest score were related to issues such as the ease of sharing digital materials $(M=4.14)$, motivating students to help each other $(M=4.12)$, and increasing collaboration $(M=4.01)$. However, items that received the lowest score were related to meeting different learning needs $(M=3.40)$, enhancing students' achievement $(M=3.28)$, and developing good personal relationships $(M=3.12)$. 
TABLE 4

TEACHERS' PERCEPTIONS OF WHATSAPP BENEFITS

\begin{tabular}{|c|c|c|c|c|c|c|c|}
\hline Benefits & $\mathbf{1}$ & 2 & 3 & 4 & 5 & M & SD \\
\hline \multicolumn{6}{|l|}{ 1. Sharing and accessing materials } & 3.91 & 0.97 \\
\hline $\begin{array}{l}\text { 1) Providing a convenient way for sharing } \\
\text { digital materials }\end{array}$ & $0.9 \%$ & $6.1 \%$ & $8.8 \%$ & $45.6 \%$ & $38.8 \%$ & 4.14 & 0.88 \\
\hline 2) Providing easy access to digital material & $1.8 \%$ & $4.4 \%$ & $15.8 \%$ & $52.6 \%$ & $25.4 \%$ & 3.95 & 0.86 \\
\hline $\begin{array}{l}\text { 3) Providing secure online learning platform } \\
\text { for sharing ideas }\end{array}$ & $5.3 \%$ & $13.2 \%$ & $14 \%$ & $47.4 \%$ & $20.2 \%$ & 3.64 & 1.10 \\
\hline \multicolumn{6}{|c|}{ 2. Creating a motivating learning environment } & 3.86 & 0.98 \\
\hline 4) Motivating students to help each other & $0.9 \%$ & $3.5 \%$ & $13.2 \%$ & $47.4 \%$ & $35.1 \%$ & 4.12 & 0.83 \\
\hline $\begin{array}{l}\text { 5) Increasing students' motivation to learn } \\
\text { Arabic language }\end{array}$ & $2.6 \%$ & $12.3 \%$ & $13.2 \%$ & $48.2 \%$ & $23.7 \%$ & 3.78 & 1.02 \\
\hline 6) Fostering participation and engagement & $4.4 \%$ & $8.8 \%$ & $21.1 \%$ & $43.9 \%$ & $21.9 \%$ & 3.70 & 1.04 \\
\hline \multicolumn{6}{|l|}{ 3. Supporting collaborative learning } & 3.74 & 1.04 \\
\hline $\begin{array}{l}\text { 7) Increasing collaboration with colleagues } \\
\text { and students }\end{array}$ & $1.8 \%$ & $7 \%$ & $12.3 \%$ & $45.6 \%$ & $33.3 \%$ & 4.01 & 0.94 \\
\hline $\begin{array}{l}\text { 8) Promoting a pleasant collaborative } \\
\text { learning environment }\end{array}$ & $4.4 \%$ & $13.2 \%$ & $15.8 \%$ & $48.2 \%$ & $18.4 \%$ & 3.63 & 1.06 \\
\hline 9) Increasing student-student collaboration & $6.1 \%$ & $7.9 \%$ & $25.4 \%$ & $41.2 \%$ & $19.3 \%$ & 3.59 & 1.07 \\
\hline \multicolumn{6}{|l|}{ 4. Providing new educational methods } & 3.50 & 1.08 \\
\hline $\begin{array}{l}\text { 10) Supporting innovative ways for language } \\
\text { education }\end{array}$ & $5.3 \%$ & $6.1 \%$ & $23.7 \%$ & $47.4 \%$ & $17.5 \%$ & 3.65 & 1.01 \\
\hline $\begin{array}{l}\text { 11) Increasing flexibility of Arabic language } \\
\text { education }\end{array}$ & $6.1 \%$ & $17.5 \%$ & $14 \%$ & $48.2 \%$ & $14 \%$ & 3.46 & 1.12 \\
\hline $\begin{array}{l}\text { 12) Providing ways for meeting different } \\
\text { learning needs }\end{array}$ & $4.4 \%$ & $19.3 \%$ & $23.7 \%$ & $36.8 \%$ & $15.8 \%$ & 3.40 & 1.10 \\
\hline \multicolumn{6}{|l|}{ 5. Improving language education } & 3.28 & 1.18 \\
\hline 13) Improving teaching effectiveness & $3.5 \%$ & $15.8 \%$ & $28.1 \%$ & $38.6 \%$ & $14 \%$ & 3.43 & 1.03 \\
\hline $\begin{array}{l}\text { 14) Enhancing students' achievement and } \\
\text { performance }\end{array}$ & $5.3 \%$ & $18.4 \%$ & $31.6 \%$ & $31.6 \%$ & $13.2 \%$ & 3.28 & 1.07 \\
\hline $\begin{array}{l}\text { 15) Developing good personal relationships } \\
\text { with students }\end{array}$ & $16.7 \%$ & $21.1 \%$ & $14.9 \%$ & $28.1 \%$ & $19.3 \%$ & 3.12 & 1.38 \\
\hline
\end{tabular}

\section{Challenges of WhatsApp}

Similarly, by using a 5-point Likert scale, participants were asked to assess 17 challenge statements. Table 5 shows the overall mean of the listed items, ranging from 4.16 to 2.34 . This indicates that participants received 13 items as challenges to WhatsApp use. By contrast, the remaining four statements were not considered significant challenges. More particularly, items that received the highest score dealt with issues such as the need for extra work and time to use $(M=4.16)$, digital divide existing among students $(M=4.09)$, providing opportunities to exchange offensive materials $(M=4.05)$, and using incorrect or colloquial Arabic language $(M=3.98)$. Conversely, items that received the lowest score dealt with issues such as resistance to WhatsApp use $(M=2.77)$, lack of student motivation $(M=2.36)$, and lack of security $(M=2.34)$.

TABLE 5

TEACHERS' PERCEPTIONS OF WHATSAPP CHALLENGES

\begin{tabular}{|l|l|l|l|l|l|l|l|}
\hline Challenge & $\mathbf{1}$ & $\mathbf{2}$ & $\mathbf{3}$ & $\mathbf{4}$ & $\mathbf{5}$ & $\mathbf{M}$ & SD \\
\hline 1) Extra work and time needed & 0 & $2.6 \%$ & $12.3 \%$ & $50.9 \%$ & $34.2 \%$ & $\mathbf{4 . 1 6}$ & $\mathbf{0 . 7 3}$ \\
\hline 2) Digital divide existing among students & $1.8 \%$ & $9.6 \%$ & $9.6 \%$ & $35.1 \%$ & $43.9 \%$ & $\mathbf{4 . 0 9}$ & $\mathbf{1 . 0 3}$ \\
\hline $\begin{array}{l}\text { 3) Providing opportunities to exchange } \\
\text { offensive materials }\end{array}$ & 0 & $6.1 \%$ & $11.4 \%$ & $53.5 \%$ & $28.9 \%$ & $\mathbf{4 . 0 5}$ & $\mathbf{0 . 8 0}$ \\
\hline 4) Using incorrect or colloquial Arabic language & $4.4 \%$ & $9.6 \%$ & $9.6 \%$ & $36 \%$ & $14.4 \%$ & $\mathbf{3 . 9 8}$ & $\mathbf{1 . 1 3}$ \\
\hline 5) Smartphones' small screen size & $3.5 \%$ & $5.3 \%$ & $11.4 \%$ & $57.9 \%$ & $21.9 \%$ & $\mathbf{3 . 8 9}$ & $\mathbf{0 . 9 2}$ \\
\hline $\begin{array}{l}\text { 6) Failure to use WhatsApp to deliver effective } \\
\text { instruction }\end{array}$ & $0.9 \%$ & $10.5 \%$ & $18.4 \%$ & $42.1 \%$ & $28.1 \%$ & $\mathbf{3 . 8 5}$ & $\mathbf{0 . 9 7}$ \\
\hline 7) Message overflowing & $2.6 \%$ & $12.3 \%$ & $13.2 \%$ & $48.2 \%$ & $23.7 \%$ & $\mathbf{3 . 7 8}$ & $\mathbf{1 . 0 2}$ \\
\hline 8) High expectation for teacher's availability & $1.8 \%$ & $10.5 \%$ & $21.9 \%$ & $48.2 \%$ & $17.5 \%$ & $\mathbf{3 . 6 9}$ & $\mathbf{0 . 9 4}$ \\
\hline $\begin{array}{l}\text { 9) The difficulty of assessing students' } \\
\text { contributions }\end{array}$ & $5.3 \%$ & $15.8 \%$ & $18.4 \%$ & $37.7 \%$ & $22.8 \%$ & $\mathbf{3 . 5 7}$ & $\mathbf{1 . 1 5}$ \\
\hline $\begin{array}{l}\text { 10) Banning communication with parents via } \\
\text { WhatsApp }\end{array}$ & $4.4 \%$ & $12.3 \%$ & $26.3 \%$ & $37.7 \%$ & $19.3 \%$ & $\mathbf{3 . 5 5}$ & $\mathbf{1 . 0 7}$ \\
\hline $\begin{array}{l}\text { 11) Confusion due to sending unrelated } \\
\text { materials }\end{array}$ & $7 \%$ & $16.7 \%$ & $20.2 \%$ & $38.6 \%$ & $17.5 \%$ & $\mathbf{3 . 4 2}$ & $\mathbf{1 . 1 6}$ \\
\hline 12) Exposure to students' personal lives & $10.5 \%$ & $21.1 \%$ & $28.1 \%$ & $29.8 \%$ & $10.5 \%$ & $\mathbf{3 . 0 8}$ & $\mathbf{1 . 1 6}$ \\
\hline 13) Increasing learning distraction & $13.2 \%$ & $25.4 \%$ & $25.4 \%$ & $17.5 \%$ & $18.4 \%$ & $\mathbf{3 . 0 2}$ & $\mathbf{1 . 3 0}$ \\
\hline 14) Lack of students' access to Internet & $11.4 \%$ & $32.5 \%$ & $27.2 \%$ & $22.8 \%$ & $6.1 \%$ & $\mathbf{2 . 7 9}$ & $\mathbf{1 . 1 0}$ \\
\hline $\begin{array}{l}\text { 15) Resistance to use due to comfort with } \\
\text { teaching status quo }\end{array}$ & $17.5 \%$ & $28.1 \%$ & $25.4 \%$ & $17.5 \%$ & $11.4 \%$ & $\mathbf{2 . 7 7}$ & $\mathbf{1 . 2 5}$ \\
\hline 16) Lack of student motivation to use/participate & $24.6 \%$ & $32.5 \%$ & $24.6 \%$ & $18.4 \%$ & 0 & $\mathbf{2 . 3 6}$ & $\mathbf{1 . 0 4}$ \\
\hline 17) Lack of security & $26.3 \%$ & $35.1 \%$ & $21.1 \%$ & $13.2 \%$ & $4.4 \%$ & $\mathbf{2 . 3 4}$ & $\mathbf{1 . 1 3}$ \\
\hline
\end{tabular}


Teachers' Gender, Age, and Teaching Experience and WhatsApp Use

The study also sought to examine the impact of teachers' gender, age, and teaching experience on their WhatsApp use. The results of this section are presented as follows.

\section{Gender and WhatsApp Use}

First, the total scores of teachers' use of WhatsApp were calculated, as they had to respond to ten WhatsApp teaching-related activities on a 5-point Likert scale. Subsequently, the teachers' scores ranged from 10 (lowest use) to 50 (greatest use), with a scale theoretical mean of 30. Then, a t-test was used where the analysis of the results revealed that there was no significant difference in the use of WhatsApp perceived by male Arabic language teachers $(M=28.88$, $S D=5.52)$ and female Arabic language teachers $(M=28.15, S D=5.31), t(112)=.702, p=.734$.

\section{Age and WhatsApp Use.}

The one-way ANOVA was used to examine the impact of teachers' age on their WhatsApp use. As shown in Table 6, there was no significant difference at the $\mathrm{p}<.05$ level in teachers' WhatsApp use based on age, $F(4,109)=1.82, p$ $=.129$.

TABLE 6

THE DIFFERENCES IN WHATSAPP USE BASED ON TEACHERS' AGE

\begin{tabular}{|l|l|l|l|l|l|}
\hline Source & Sum of Squares & df & Mean Square & F & Sig. \\
\hline Between Groups & 205.839 & 4 & 51.460 & 1.826 & .129 \\
\hline Within Groups & 3072.231 & 109 & 28.186 & & \\
\hline Total & 3278.070 & 113 & & & \\
\hline
\end{tabular}

Teaching Experience and WhatsApp Use

As shown in Table 7, an analysis of variance (ANOVA) revealed that there was a significant difference at the $p<.05$ level in teachers' WhatsApp use based on their teaching experience, $F(4,110)=2.91, p=.038$.

TABLE 7

THE DIFFERENCES IN WHATS APP USE BASED ON TEACHERS' TEACHING EXPERIENCE

\begin{tabular}{|l|l|l|l|l|l|}
\hline Source & Sum of Squares & df & Mean Square & F & Sig. \\
\hline Between Groups & 241.433 & 3 & 80.478 & 2.915 & .038 \\
\hline Within Groups & 30.36 .637 & 110 & 27.606 & & \\
\hline Total & 3278.070 & 113 & & & \\
\hline
\end{tabular}

Afterward, a Tukey HSD post hoc test was utilized to explore the differences between each group and other groups. The results, as shown in Table 8, revealed that there was a significant difference in WhatsApp use between teachers with 6-10 years of experience $(M=26.96, S D=5.25)$ and more than 15 years $(M=31.47, S D=4.33)$ in favour of those with more teaching experience at $p=.026$. Lastly, the Tukey HSD test suggested that there was no significant difference between any other groups.

TABLE 8

TUKEY HSD TEST OF WHATSAPP USE BY TEACHING EXPERIENCE

\begin{tabular}{|l|l|l|l|l|}
\hline $\begin{array}{l}\text { (I) Teaching } \\
\text { Experience }\end{array}$ & $\begin{array}{l}\text { (J) Teaching } \\
\text { Experience }\end{array}$ & $\begin{array}{l}\text { Mean Difference } \\
(\mathrm{I}-\mathrm{J})\end{array}$ & Std. Error & Sig. \\
\hline \multirow{5}{*}{$1-5$} & $6-10$ & 1.13125 & 1.18945 & .777 \\
\cline { 2 - 5 } & $11-15$ & -1.16667 & 1.54677 & .875 \\
\cline { 2 - 5 } & More than 15 & -3.37059 & 1.47512 & .108 \\
\hline \multirow{5}{*}{$6-10$} & $1-5$ & -1.13125 & 1.18945 & .777 \\
\cline { 2 - 5 } & $11-15$ & -2.29792 & 1.64410 & .504 \\
\cline { 2 - 5 } & More than 15 & $-4.50184 *$ & 1.57688 & .026 \\
\hline \multirow{5}{*}{$11-15$} & $1-5$ & 1.16667 & 1.54677 & .875 \\
\cline { 2 - 5 } & $6-10$ & 2.29792 & 1.64410 & .504 \\
\cline { 2 - 5 } & More than 15 & -2.20392 & 1.86125 & .638 \\
\hline \multirow{3}{*}{ More than 15 } & $1-5$ & 3.37059 & 1.47512 & .108 \\
\cline { 2 - 5 } & $6-10$ & $4.50184 *$ & 1.57688 & .026 \\
\cline { 2 - 4 } & $11-15$ & 2.20392 & 1.86125 & .638 \\
\hline
\end{tabular}

\section{The Relationship between Use, Competence, Benefits, and Challenges}

Pearson Correlation was used to examine the relationship between Arabic language teachers' use and their perceptions of competence, benefits, and challenges of WhatsApp. It was affirmed that there was a small positive significant relationship between teachers' use and their perceived competence, $r(114)=.25, p=.009$. The results also indicated that there was a medium positive significant relationship between use and perceived benefits, $r(114)=.39, \mathrm{p}$ $<.001$. Lastly, a small negative significant relationship was found between use and perceived challenges, $r(114)=-.19$, $p=.044, a=.05$.

\section{DISCUSSION}


The findings of the current study provide substantial information and evidence related to Arabic language teachers' perceived usage, benefits, and challenges of WhatsApp instant messaging as an educational tool. Those findings are discussed in the section below.

In addressing the issue related to Arabic language teachers' competence of using WhatsApp to support their teaching practice, the study data revealed that a significant number of participants indicated that they are skillful users, with $44 \%$ of them considering themselves as advanced or expert WhatsApp users. The high level of competence in using WhatsApp could refer to its high level of popularity and acceptance among educators as a free, available, and userfriendly smartphone app (Bouhnik \& Deshen, 2014; Mwakapina, 2016; So, 2016). However, the remaining participating Arabic language teachers (56\%) indicated that they possess an intermediate or beginner level of WhatsApp use. Consistently, participating Arabic language teachers considered that failure to use WhatsApp to deliver effective instruction was challenging. This entails the inevitability of providing them with the appropriate professional development for mobile apps integration (Aburezeq \& Ishtaiwa, 2013; Ishtaiwa, Khaled, \& Dukmak, 2015).

With regard to Arabic teachers' use of WhatsApp for educationally related work, they highly used WhatsApp for sharing and accessing language materials and moderately for chatting purposes, creating online learning groups, and providing written or audio feedback. The type of use could refer to their perceived ease of use and usefulness of employing such mobile teaching and learning activities (Davis, Bagozzi, \& Warshaw, 1989). This indicates that Arabic language teachers tended to use easy and beneficial WhatsApp features. On the other hand, Participating Arabic language teachers minimally used WhatsApp for making voice calls, chatting with parents, conducting synchronous online activities, and conducting online assessments as a way to support their Arabic teaching.

The poor use of such WhatsApp activities could be justified by the challenges of WhatsApp use in Jordan, including instructional, educational, cultural, and technical challenges. More particularly, participants in the study identified a variety of different challenges to WhatsApp use as an educational tool. Most notably is the need for a huge amount of work and time for conducting WhatsApp teaching-learning activities. Extra work and time are needed to design online activities, facilitate and monitor groups' work, read a vast amount of messages, and provide feedback. Given the fact that most Arabic language classes in Jordan are categorized under large class size, all those activities are difficult to be effectively achieved. Digital divide existing among students presents another major challenge. It is worth pointing out that unavailability of smartphones for all students may limit teachers' integration of such apps into their teaching practice. Another important challenge is the fear of students' improper use of WhatsApp. This includes two important issues. The first is that use of WhatsApp could provide an opportunity to exchange offensive material. Therefore, there are many voices among stakeholders (teachers, administrators, and parents) calling for banning mobile devices in schools. It is evident that some stakeholders still perceive mobile devices as dangerous tools. It is a culture issue, where they think that allowing students to use mobile apps may encourage them to commit improper behaviours, such as developing relationships with others from the opposite sex or exchanging inappropriate materials, including offensive language, images, and audio or video clips (Mwakapina et al., 2016; United Nations Educational, Scientific and Cultural Organization/UNESCO, 2012). The other issue related to improper use of WhatsApp is using incorrect or colloquial Arabic language, which ultimately and negatively impacts students' language proficiency related to vocabulary, spelling, and grammar skills. Participants highlighted smartphones' small screen size as an additional major challenge. Teachers might feel uncomfortable using their mobile phone for a long time as a result of eye strain and stress caused by looking at a small screen. These findings mirror the findings of other research conducted in different regions (Aburezeq \& Ishtaiwa, 2013; Bouhnik \& Deshen, 2014; Gon \& Rawekar, 2017; Rankin, 2010; Salem 2013).

Although there exist many challenges to WhatsApp use, Arabic language teachers perceived WhatsApp as a valuable educational tool. It has been mainly viewed as a powerful tool for sharing and accessing learning material, creating a motivating learning environment, supporting collaborative learning, providing new educational methods, and improving language education. One of the main strengths of WhatsApp lies in its capability to offer an authentic, interesting, and different learning environment where students can share materials, discuss ideas, construct meaning, help each other, and evaluate and reflect on their performance whenever and wherever (Aburezeq \& Ishtaiwa, 2013; Andújar-Vaca \& Cruz-Martínez, 2017; Hou \& Wu, 2011; Mwakapina, 2016). Overall, WhatsApp provides a new educational tool that boosts accessibility of learning content, augments collaboration, strengthens interests, and encourages autonomous learning to help students actively participate and take control of their learning practice (Bere, 2013; Boticki et al., 2015). All those features can eventually advance students' performance and achievement (So, 2016).

It was also found that there was no significant difference in teachers' use of WhatsApp based on gender and age. This finding could be attributed to the type of WhatsApp activities that have been employed by participants. As indicated above, participants concentered on very few features of WhatsApp, while many other features were inadequately utilized as a result of many challenges identified. At the same time, and surprisingly enough, the study found that there was a significant difference in teachers' use of WhatsApp based on teaching experience in favour of those with more years of experience. This interesting finding could be explained by the ease of use of WhatsApp in comparison to other collaborative tools that require a high level of technology skills. However, both findings regarding differences in WhatsApp use suggest re-investigating WhatsApp use by employing a larger and more diverse study sample. 
Conclusively, a positive significant relationship between teachers' use and their perceived competence was found, indicating that teachers with a higher level of competence of WhatsApp tended to use it more often. The results also indicated that there was a positive significant relationship between use and perceived benefits. This means that more use of WhatsApp assisted teachers to identify more benefits of it as an educational tool. Furthermore, a negative significant relationship was found between use and perceived challenges, meaning that more use of WhatsApp led to identifying fewer challenges.

\section{CONCLUSION AND ReCOMMENDATIONS}

Use of WhatsApp as an educational tool could open a new avenue for supporting Arabic language teaching and learning. With WhatsApp, teachers and their students are enabled to directly and conveniently access a lot of digital learning resources with different formats, including text, images, videos, and voice notes. It allows teaching and learning anytime and anywhere. This has made WhatsApp as a new, motivating, interesting, and valuable collaborative language-learning tool. While benefits of WhatsApp are obvious, there are a number of challenges that cannot be ignored and should be addressed to expand teachers' use. To achieve the benefits of WhatsApp and address its challenges, the below recommendations are provided.

- Arabic language teachers should be encouraged to use WhatsApp as an educational tool. This includes providing them compensation for extra effort and time used for WhatsApp use.

- Since Arabic language teachers have different levels of WhatsApp competence and integration skills, sufficient and appropriate professional development activities on WhatsApp integration need to be provided to equip them with the essential skills.

- As many challenges of WhatsApp refer to the lack of awareness of the proper use of WhatsApp, a clear policy and criteria for WhatsApp use should be outlined.

- The benefits of WhatsApp use as an educational tool need to be advertised to all stakeholders. This will reduce some of the negative views towards mobile devices, if there are any, and will lead to providing teachers with the needed support to enhance their WhatsApp use.

- Additional qualitative and quantitative research projects, including a bigger and more diverse sample size from different cities, and employing different research methods are needed to entirely understand the issues related to WhatsApp use.

\section{REFERENCES}

[1] Abdul Fattah, S. (2015). The effectiveness of using WhatsApp messenger as one of mobile learning techniques to develop students' writing skills. Journal of Education and Practice, 6 (32), 115-127.

[2] Aburezeq, I., \& Ishtaiwa, F. (2013). The impact of WhatsApp on interaction in an Arabic language teaching course. International Journal of Arts and Sciences. 6(3), 165-180.

[3] Al Shekaili, B. (2016). Investigating teachers' actual levels of use of WhatsApp application with English foundation and credit program students at Sultan Qaboos University in Oman. Journal of Teaching English for Specific and Academic Purposes, 4(1), 39-48.

[4] Amry, A. B. (2014). The impact of WhatsApp mobile social learning on the achievement and attitudes of female students compared with face to face learning in the classroom. European Scientific Journal, 10(22), 116-136.

[5] Andújar-Vaca, A., \& Cruz-Martínez, M. S. (2017). Mobile instant messaging: WhatsApp and its potential to develop oral skills. Media Education Research Journal, 25(50), 43-52.

[6] Baek, Y., Zhang, H., \& Yun, S. (2017). Teachers' attitudes toward mobile learning in Korea. Turkish Online Journal of Educational Technology, 16(1), 154-163.

[7] Bere, A. (2013). Using mobile instant messaging to leverage learner participation and transform pedagogy at a South African University of Technology. British Journal of Educational Technology, 44(4), 544-561.

[8] Boticki, I., Baksa, J., Seow, P., \& Looi, C. (2015). Usage of a mobile social learning platform with virtual badges in a primary school. Computers \& Education, 86, 120-136.

[9] Bouhnik, D., \& Deshen, M. (2014). WhatsApp goes to school: Mobile instant messaging between teachers and students. Journal of Information Technology Education, 13, 217-231.

[10] Cavus, N., \& Ibrahim, D. (2009). M-learning: An experiment in using SMS to support learning new English language words. British Journal of Educational Technology, 40 (1), 78-91.

[11] Cheung, W., Hew, K., \& Ng, S. (2008). Toward an understanding of why students contribute in asynchronous online discussions. Journal of Educational Computing Research, 38(1), 29-50.

[12] Churchill, D., \& Wang, T. (2014). Teacher's use of iPads in higher education. Educational Media International, 51(3), $214-225$.

[13] Cifuentes, O., \& Lents, N. (2010). Increasing student-teacher interactions at an urban commuter campus through instant messaging and online office hours. Electronic Journal of Science Education, 14(1), 1-13.

[14] Davis, F. D., Bagozzi, R. P., \& Warshaw, P. R. (1989). User acceptance of computer technology: Comparison of two theoretical models. Management Science, 35(8), 982-1003.

[15] Dhir, A., Gahwaji, N. M., \& Nyman, G. (2013). The role of the iPad in the hands of the learner. Journal of Universal Computer Science, 19(5), 706-727.

[16] Domingo, M., \& Garganté, A. (2016). Exploring the use of educational technology in primary education: Teachers' perception of mobile technology learning impacts and applications' use in the classroom. Computers in Human Behavior, 56, 21-28. 
[17] Furió, D., Juan, M., Seguí, I., \& Vivó, R. (2015), Mobile learning vs. traditional classroom lessons: A comparative study. Journal of Computer Assisted Learning, 31, 189-201.

[18] Gon, S., \& Rawekar, A. (2017). Effectivity of e-learning through WhatsApp as a teaching learning tool. MVP Journal of Medical Sciences, 4(1), 19-25.

[19] Hamad, M. (2017). Using WhatsApp to enhance students' learning of English language "Experience to Share". Higher Education Studies, 7(4), 74-87.

[20] Hou, H., \& Wu, S. (2011). Analyzing the social knowledge construction behavioral patterns of an online synchronous collaborative discussion instructional activity using an instant messaging tool: A case study. Computers \& Education, 57(2), 1459-1468.

[21] Ishtaiwa, F. (2014). Mobile technology as a learning tool: Use and effects. International Journal of Communication and Information Technology Education, 10(4), 1-15.

[22] Ishtaiwa, F., Khaled, A., \& Dukmak, S. (2015). Faculty members' perceptions of the integration, affordances, and challenges of mobile learning. International Journal of E-Learning \& Distance Education, 30(2), 1-20.

[23] Kinash, S., Brand, J., \& Mathew, T. (2012). Challenging mobile learning discourse through research: Student perceptions of blackboard mobile learn and iPads. Australasian Journal of Educational Technology, 28(4), 639-655.

[24] Klopfer, E., Squire, K., \& Jenkins, H. (2002). Environment detectives: PDAs as a window into a virtual simulated world. Proceedings of IEEE International Workshop on Wireless and Mobile Technologies in Education (pp. 95-98). Vaxjo, Sweden: IEEE Computer Society.

[25] Lu, J., Meng, S., \& Tam, V. (2014). Learning Chinese characters via mobile technology in a primary school classroom. Educational Media International, 51(3), 166-184.

[26] Lu, M. (2008). Effectiveness of vocabulary learning via mobile phone. Journal of Computer Assisted Learning, 24, 515-525.

[27] Maria, J. (2016). Use of WhatsApp to enhance reading and writing skills at undergraduate college level. Language in India, $16(11), 47-60$.

[28] Murphy, G. (2011). Post-PC devices: A summary of early iPad technology adoption in tertiary environments. E-Journal of Business Education \& Scholarship of Teaching, 5(1), 18-32.

[29] Mwakapina, J. (2016). Grammar for successful written discourse: Are the ESL/EFL students in Tanzania universities truly learning? International Journal of Education and Research, 4(3), 309-322.

[30] Mwakapina, J., Mhandeni, A., \& Nyinondi, O. (2016). WhatsApp mobile tool in second language learning: Opportunities, potentials and challenges in higher education settings in Tanzania. International Journal of English Language Education, 4(2), $70-90$.

[31] Peng, H., Su, Y., Chou, C., \& Tsai, C. (2009). Ubiquitous knowledge construction: Mobile learning redefined and a conceptual framework. Innovations in Education and Teaching International, 46(2), 171-183.

[32] Plana, M., Escofet, M., Figueras, I., Gimeno, A., Appel, C., \& Hopkins, J. (2013). Improving learners' reading skills through instant short messages: A sample study using WhatsApp. 4th World-CALL Conference, Glasgow, 10-13 July 2013.

[33] Rankin, S. L. (2010). The impact of text messaging language shortcuts on developmental students' formal writing skills. Dissertations/Theses - Doctoral Dissertations, Retrieved 22/2/2018 from http://gateway.proquest.com/openurl?url_ver=Z39.882004\&rft_val_fmt=info:ofi/fmt:kev:mtx:dissertation\&res_dat=xri:pqdiss\&rft_dat =xri:pqdiss:3427225.

[34] Salem, A. (2013). The impact of technology (BBM and WhatsApp applications) on English linguistics in Kuwait. International Journal of Applied Linguistics \& English Literature, 2(4), 64-69.

[35] So, S. (2016). Mobile instant messaging support for teaching and learning in higher education. The Internet and Higher Education, 31, 32-42.

[36] Sung, Y., Chang, K., \& Liu, T. (2016). The Effects of integrating mobile devices with teaching and learning on students' learning performance: A meta-analysis and research synthesis. Computers \& Education, 94, 252-275.

[37] United Nations Educational, Scientific and Cultural Organization. (2012). Mobile learning for teachers in Africa and the Middle East: Exploring the potential of mobile technologies to support teachers and improve practice. Paris: United Educational, Scientific and Cultural Organization. Retrieved 10/1/2018 from: http://unesdoc.unesco.org/images/0021/002163/216358e.pdf.

[38] Vrocharidou, A., \& Efthymiou, I. (2012). Computer mediated communication for social and academic purposes: Profiles of use and university students' gratifications. Computers \& Education, 58(1), 609-616.

[39] Vygotsky, L. S. (1978). Mind in society: The development of higher psychological processes. Cambridge, MA: Harvard University Press.

[40] Yeboah, J., \& Ewur, G. (2014). The impact of WhatsApp messenger usage on students'performance in tertiary institutions in Ghana. Journal of Education and Practice, 5(6), 157-164.

[41] Zhang, H., Song, W., \& Burston, J. (2011). Reexamining the effectiveness of vocabulary learning via mobile phones. The Turkish Online Journal of Educational Technology, 10(3), 203-214.

Suad Al-Waely born in Baghdad in 1970, has obtained a BA degree in Arabic from the College of Education/ University of Baghdad/ 1991, Master of the Arabic language curricula and teaching methods/ Faculty of Education/ University of Baghdad/ 1996, Ph.D. in Arabic language curricula and teaching methods / Faculty of Education/ University of Baghdad/ 1998

She is Associate Professor at the Hashemite University in Jordan, And it has many of the research, such as: Analysis of Islamic values in songs Arabic language books for the first three rows of basic education in Jordan, Damascus University Journal for Educational and Psychological Sciences, University of Damascus 05/23/2011. Using Blogs to Facilitate and Effective Learning: Perceptions of Pre-Service Arabic Teachers. International Journal of Instructional Media Westwood Press, Inc. United States, October 25, 2011. The impact of training on critical reading skills in reading achievement and the trend towards the Arabic language, Mutah University magazine, 2012. 